\title{
Correction to: Log-based rock compressibility estimation for Asmari carbonate formation
}

\author{
Rahman Ashena ${ }^{1}$ ( ) Peter Behrenbruch ${ }^{1}$ - Ali Ghalambor ${ }^{2}$
}

Published online: 1 December 2021

(c) The Author(s) 2021

\section{Correction to: \\ Journal of Petroleum Exploration and Production Technology (2020) 10:2771-2783 https://doi.org/10.1007/s13202-020-00934-0}

In the original publication of the article Overburden pressure in equation 6 (page 3), the measuring unit should be in psi (not psi-1) 2. Also, the pore pressure in equation 6 (page 3), the measuring unit should be in psi (not psi-1).

This has been corrected in this paper.

Open Access This article is licensed under a Creative Commons Attribution 4.0 International License, which permits use, sharing, adaptation, distribution and reproduction in any medium or format, as long as you give appropriate credit to the original author(s) and the source, provide a link to the Creative Commons licence, and indicate if changes were made. The images or other third party material in this article are included in the article's Creative Commons licence, unless indicated otherwise in a credit line to the material. If material is not included in the article's Creative Commons licence and your intended use is not permitted by statutory regulation or exceeds the permitted use, you will need to obtain permission directly from the copyright holder. To view a copy of this licence, visit http://creativecommons. org/licenses/by/4.0/.

Publisher's Note Springer Nature remains neutral with regard to jurisdictional claims in published maps and institutional affiliations.

The original article can be found online at https://doi.org/10.1007/ s13202-020-00934-0.

Rahman Ashena

ashena.rahman@gmail.com

Bear and Brook Consulting, Brisbane, Australia

2 Oil Center Research International, Louisiana, USA 